\title{
Public Service Announcements to promote integration of people with Down Syndrome: a synchronic analysis
}

\author{
Concepción Hernández Guerra ${ }^{1}$ · (1) https://orcid.org/0000-0001-9073-1736 \\ Universidad de Las Palmas de Gran Canaria \\ Departamento de Filología Moderna, Traducción e Interpretación, C/ Pérez del Toro, $1 \cdot$ E35003 $\cdot$ Las Palmas de Gran Canaria . \\ Spain
}

ABSTRACT

The aim of this paper is to undertake a study on advertisements released on YouTube concerning integration of people with Down Syndrome. This study was based on the different elements included (visual, audio and dialogues) in the advertisements, which were done in both Spain and the United States in the year 2018 commemorating the International day.

As everybody knows, developed countries have as one of their social objectives to promote tolerance and acceptance of the different minority groups no matter the condition: race, genre, sexual orientation, different capacities, etc. This is an aim recognised in every country to be considered developed and with a forward-looking thinking. In order to perform this, associations and organisms try to attract the attention of the citizens through advertisements in which sameness and equality among people is the main message. To do this, language and images play a decisive role. However, these videos are not considered advertisements as such as their aim is social and not mercantilist. Therefore, features will vary. We shall analyse these resources and conclude with the degree of efficacy.

Keywords - public service advertisements, integration, international Down Syndrome day

RESUMEN

En una sociedad en la que el aprendizaje ubicuo o u-learning (anytime, anywhere) forma parte del día a día y en la que la enseñanza de una segunda lengua (L2) ya no se considera un sistema estricto de reglas sino un sistema para lograr una comunicación eficiente, el podcast se presenta como un recurso didáctico que ayuda a los discentes a desarrollar la comprensión auditiva, tanto interna como externa. La finalidad de este artículo es la realización de una propuesta didáctica en la que se integra el uso externo del podcast como recurso en la enseñanza de una L2, en este caso, el inglés, no solo para que el alumnado mejore en esta destreza, sino también para que disminuya su nivel de ansiedad y aumente su autoestima, factores clave en el aprendizaje de una lengua. En el estudio se realizó un cuestionario para determinar si el uso del podcast y las actividades propuestas habían resultado positivas y motivadoras en cuanto a la mejora de la comprensión auditiva. Los primeros resultados muestran que este recurso no solo posee ventajas didácticas en relación con la comprensión auditiva, sino que puede ser utilizado como refuerzo para que los discentes mantengan el contacto con la L2 fuera del aula.

Palabras clave - anuncios, integración, día mundial del Síndrome de Down

\section{Introduction}

Stated in a simple way, the purpose of advertising is to attract people's attention in order to sell a product. The ways of getting this are varied and the balance between originality and, at the same time, straightness is what makes an advertisement be successful. The fact of getting people talk and notice the product is just the purpose of the elaboration and launching. Anyhow, the traditional vision of advertising is changing. 
Advertising is commonly defined as paid, one-way promotional communication in any mass media (Tuten, 2008: 3). The American Marketing Association defines advertising as

the placement of announcements and persuasive messages in time or space purchased in any of the mass media by business firms, nonprofit organizations, government agencies, and individuals who seek to inform and/or persuade members of a particular target market or audience about their products, services, organizations or ideas. (Tuten, 2008: 3)

Advertising is now explained by using different methods. The most common methods are print advertising and online advertising but there are others like mobile and outdoor advertising. All of them show differences. Labrador et al. (2014) note the aspect called "consumer profile": online advertisements are sought out by clients, not as what happens with print newspapers in which readers come across the advert. Another feature that distinguishes online from print advertisements is the extension. Online advertisements can be longer than expected in order to claim for more detailed information, and not just short attention-grabbing. Indeed, in this online subgenre we are facing texts that mix the promotion of the product with other characteristics which are taken from the informative genre.

Added to this, advertisers recognize that persuasion is not achieved exclusively by means of linguistic resources; all the visual elements also contribute to the communicative function of advertising. That is, the semiotic aspect is also important and online examples own more freedom to add pictures, moving images or even insert short demo videos.

To this, Labrador et al. (2014) add that online advertisements present two compulsory moves: identifying product and purpose, on the one hand; and describing the product, on the other. They are also accompanied by some pictures of the product. Online advertisements are admittedly distinguished because they provide more extended information than products seen in other media. Additionally, the description is commonly led to people that have some previous knowledge of the product, not for fresh buyers. Thus, the two moves named above are developed traspassing the limit of just catching the attention of the reader.

Whereas, on the one hand, Yang et al. (2017: 814) extend this information stating that "when consumers watch online advertising, they may need to know the product information (informativeness), plus some enjoyment or emotional release (entertainment) and trust of the product or brand (credibility)", on the other hand, Schlosser et al. (1999) wrote a study that viewed internet advertisements as more informative and trustworthy thanks to a great extent to the characters, real protagonists of the message they demand.

At the same time, YouTube videos are popular. Studies have shown that over six billion hours of video are watched monthly on YouTube and over 100 hours of video are uploaded to YouTube every minute. The exponential growth of social media in contemporary society makes them necessary tools for communication, content, creation, sharing, and business growth (Kaplan and Haenlein, 2010). Feroz and Vong (2014) study the reasons why some videos are viral and others not. They state that literature related to content hypothesis points to attractiveness (Gladwell, 2002; Porter and Golan, 2006), usefulness (Pousttchi and Wiedemann, 2007), and emotional aspect of content (Berger and Milkman, 2009) in viral phenomenon. There are other elements that intervene like the structure, characteristics of the recipients, seeding strategies, and role of influential users but for the purpose of our paper the first of the characteristics is what deserves being analysed.

Likewise, non-commercial advertisements are those that integrate online advertising with social awareness with the purpose of charity or political propaganda. For this type new terms have been coined, as Public Service 
Announcements, netvertising, social marketing or corporative advertisements. All of them have in common that the purpose is not commercial but altruist or to open consciences on serious problems in our society.

The purpose of the paper is to show a thorough analysis of the advertisements released and the impact which they have had. We shall analyse the elements used in the elaboration to conclude which are the preferred by the viewers.

We shall divide this paper into the following sections: first, some literature review is offered related to the spoken discourse in advertisements. To be more specific, we shall deal with the types of non-commercial advertisements in YouTube videos. Next section will be dedicated to Down Syndrome, the condition and the informative campaigns. We shall focus on those campaigns which have been done in Spain and in the United States. Next sections will be focused on the sample, results and discussion in which we shall try to analyze the common elements that make them be viral and the possible differences in every country, to end with the conclusions.

\section{Literature Review}

The first step will be to narrow the genre in which this corpus is studied. As McCarthy (1998: 29) states, genres must be recognised as the common elements easily recognisable for participants within "discourse communities" and adds that some studies are based on the mixing of activities that characterise genres. In fact, Duranti (1983: 1) had argued for a dynamic view of genres: "the same genre can be performed in different ways according to the particular event, depending on who the speakers are, what their purposes are, where the genre occurs in sequence in the speech event, etc.".

The starting point must be the division between written and oral texts. This is the reason why Aijmer (2004: 1) distinguishes between text linguistics, in which we work with printed records and discourse analysis, that is, spoken texts or discourses; however, Brown \& Yule (1986: 3) use text to refer to "the verbal record of a communicative act whether spoken or written". Biber (1988) states the need to establish a clear line between written and speech production and Cook (1992: 92) adds that discourse analysis analyses discourse in context not just as a random set of sentences, "discourse is text and context together, interacting in a way which is perceived as meaningful and unified by the participants."

This short introduction leads to the topic of the paper because the language of advertising shows some complexities. Indeed, researchers recognize the difficulty to cope with advertising (Cook, 1992: 112) because of the wide scope it covers and also because "the words in contemporary advertisements are carefully scripted and subjected to so much scrutiny and rewriting that in this respect they stand comparison with the drafting of laws or poetry." Secondly, advertising has evolutioned since its origins and the wide variety of ways to sell the product and services make it even more difficult to narrow it down. In recent times, we also see how language, pictures and music play a remarkable role.

Furthermore, not all the products exhibited are with commercial reasons. In other occasions, it must be spread for charity or social purposes This leads to linguists to coin new terms. As said above, some of them are Corporate Advetisements to identify advertisements not produced to sell a product but to spread an idea. Benefits are indirect and long-term. Secondly, Netvertising covers all those advertisements produced and distributed on the internet. They can be through websites, blogs, social networks or online games and make use of audio or visual resources (Boitor, 2011: 12). Related to this, Social Marketing is the "application of commercial marketing technologies to the analysis, planning, execution and evaluation of programs designed to influence 
the voluntary behaviour of target audiences in order to improve the personal welfare and that of their society." (Andersson 1995: 7 in Fuhrel-Forbis, 2011). Finally, Social-media Marketing implies the uses of social networks (e.g. YouTube videos) to meet branding and communicative objectives, which can be, firstly, to encourage interaction between consumers and brands and, secondly, what is called "Brand as person", i.e. to personalize the product (Tuten, 2008: 19). In few words, to distinguish themselves from other advertisements and set the stage for a perceived relationship. In the debate of social marketing, one of the most recurrent means to communicate with the public is by Public Social Advertisements (PSA).

\subsection{Public Service Advertisements}

Government departments face the same challenge as brand owners seeking to influence their potential consumer: the need to gain the attention of an audience and to deliver a message (Collins 2008: 131) but the problem arises when the message cannot be seen or heard by the audience. The audience is not a passive receiver but filters what the are really interested in. in few swords, the message must be successfully communicated and this can be achieved by different means, such as entertainment, participation, intrigue or humour, among others.

Secondly, one key aim in this type of publicity is challenging the audience's minds (Storey 2008: 13). That is, the change the attitude and vision a whole society has of certain issues. The most common are decrease the number of fatalities and reduce injuries and deaths from domestic fires, among others. As we see, the difference with common advertising is related to attitude, to change habits in our daily life. The changing of these new behaviours is not as simple as to buy a different brand in a supermarket but, rather, to change deep ideas which we have ingrained. Storey (2008) continues explaining the different themes that advertisers work with when elaborating these adverts. One of them is what he calls "overcoming denial: it's not me" meaning that, when this does not affect me, I just ignore. We consider that certain things will not happen to us as the possibilities are very low in percentage. For instance, my children do not have Down Syndrome and, thus, I do not have to feel sympathy for them, or it is very unlikely that I do have a child with Down Syndrome.

Another purpose is to change the way people perceive a specific situation. They feel it so distant to reality that campaigns seek to get them closer to the different collectives by showing proximity. This distance is mainly produced because of myth and disinformation of the topic. Therefore, the best way to avoid it is to show the reality as it is shown. In this case, Storey (2008: 29) claims "the creative challenge is to find ways of depicting a scenario as entirely credible and realistic, without being so specific that audiences can excuse themselves."

Other campaigns are focused on gropus at risk. For instance, making young people be aware of the dangers of alcohol. The reaction of those adverts can be received adversely as adolescents do not perceive such damage and the message is seen as exaggerated.

PSA is the most common platform in which non-profit organizations rely on. Thus, the most important difference between an advertisement and a PSA is the aim of the message. In the case of PSAs there is no commercial interests but, on the contrary, to deliver a message to the community. As stated, non-profit organizations may use familiar images and situations to create a new context for understanding claims of compassion as a strategy to address the problem of desensitized publics. In fact, PSA videos are normally led to health-awareness, such as eating disorders, texting while driving, etc. in which the aim is to change habits. Some statistics can be drawn at the end of the campaign stating the reduction or not of this problem. In the case of tolerance and integration it is more difficult to evaluate: there are no statistics that measure the impact, the acceptance is measured just for 
the number of viewers and shares of the video.

These videos would be included in what Cook (1992: 10) calls non-product advertisements, those for charities and political parties, to distinguish from product advertisements, that are traditional.

There are two types of PSA videos: perceived similarity videos and perceived expertise videos (Pack 2011). The perceived similarity videos are those created by someone from a perceivably similar group. That is, the promotion of a minority group recorded by members of that group. This is considered more effective than others produced by an expert or organisation. The case that individuals reflect their experience in first person brings realism to the delivery.

Furthermore, perceived expertise videos are produced by expert companies in that topic. In some occasions, they refer to a communicator's or message's positive characteristics. In other words, it "is the degree to which message receivers perceive a communication to convey relevant knowledge, skill or experience." (Pack 2011: 175) Along with credibility or trustworthiness, messages are straight, well-prepared and original examples.

For some issues the first type is more effective as long as viewers value similar or close experiences to them as more emphatic than others in which they do not see themselves represented. For instance, according to social influence literature, young individuals respond more favourably to messages produced by someone like themselves (Pack 2011: 179). At the same time, they consider those delivered by experts more trustworthy for the quality and authority they own.

This is accomplished with the use of audio, video and dialogues of the characters. Dialogues are "casual conversation" examples. Casual conversation displays a variety of features which have led to ask whether it should be considered a genre or not. Anything goes in this format. Yet casual conversation is no less goal-driven than any other type of talk.

Advertisements contain many elements: participants, function, substances, pictures, music, a society, paralanguage, language, a situation, other advertisements and other discourses. Every single element provides a perspective of the product offered. In our sample, not all the elements have an equal concern. This idea linked with the above mentioned of the difference between perceived similarity and expertise videos lead us to see major differences in the use of these elements, as it will be seen later.

For all the stated reasons, in the analysis of advertisements theories of language used traditionally are not always helpful. What is relevant is the deep meaning and intention of the message. Actually, when talking about advertisements there has been a move from studying the language towards their function. Language is then analysed since it is recognised as having a value that contains information or emotion, or has a practical or social purpose (Cook 1992).

Finally, tolerance is a topic worked from different associations and organisms. The trend in the developed countries is to promote integration and respect for what is different, no matter the reason. Therefore, from universities to local govenments it is necessary and even fashionable to dedícate an allocation of the budget to promote these virtues. Otherwise, institutions could be signalled as little democratic and not open to diversity. The way of showing this approach can be through posters in special days, advertisements and promises in campaigns where politicians mention the most remarkable minorities in the country. Thus, for instance, many universitites around the world have research groups dedicated to integration of the different religions and/or races and they offer subjects that deal with this aim. In the United States, a country conceived with people from 
so many different countries, this argument can not be taken for granted. Big efforts are being done in civilised countries and some steps have been taken.

People with Down Syndrome commemorate their day the 21st of March as this date makes reference to their condition: an extra cromosome (3 instead of 2) in the pair number 21. Moeover, in 2018 the United Nations celebrated the 13th year that recalls the rights of this collective. Campaigns are done in different languages and an annual congress is held. In it future lines to be accomplished by the different governments are established in order to normalize theis people's presence in the society and labour market.

This is the organism itself but, as said before, every single country and local govenment have their own campaigns with the collaboration of the associations to spread the ideas of tolerance, inclusion and acceptance. In this paper we shall analyse the different advertisements published on the designated date in two different countries. The purpose is to highlight and analyse the elements used in the promotion and the different characteristics which they own.

\section{Down Syndrome Public Service Advertisements}

Most advertisements are released in YouTube rather than on television or cinemas for economic reasons. Also, people spend longer hours in front of the computer than in front of the television and YouTube has a prominent role on the internet. Pulbic Service Advetisements are not unfamiliar with these circumstances. Given that in many occasions are home-made videos and non-profit bodies.

On this basis, the first thing to consider is the distinction between elaborated and spontaneous videos. This pairing can be compared to some extent with expertise and similarity videos named above although spontaneous and similarity do not have the same boundaries. Some of them are done with people with Down Syndrome. They are homemade videos in which anonymous people want to share their experience. They are widely appreciated because in some aspects they provide some difference regarding authenticity in contrast with traditional advertisements as we know them (Sádaba \& Rendueles 2016). They are quite spontaneous and in many occasions unconventional.

Moreover, elaborated and expertise videos have been done by associations with the collaboration of professional advertising companies. That is, they are official videos carried out with a thorough study.

\section{Sample}

For the synchronic study presented here, we have chosen the videos released in the year 2018 commemorating the world Down Syndrome Day. The gathering of the data was taken the very same day and just for the videos released in Spain and the States as examples of developed countries. We have omitted the videos from other English and Spanish-speaking countries. As the sample has been gathered the next day to the official date, the analysis was done to the videos released that specific day: 36 videos in all, 18 from each country.

The aim of these videos is evident: to normalize the integration of this collective as citizens with the same rights and opportunities; the environment and content in which this happens differ. The protagonists have in common their condition or not. Moreover, they are shown in different situations. 
The slogans of the videos reflect the main idea or purpose of the record. Rey-Debove (see Aijmer, 2004) defines slogans as metalinguistic proper names in which they are meant for designating the text (21). Additionally, Rowse \& Fish (2005: 145) distinguish three different functions: 1) to attract attention; 2) to arouse interest; and $3)$ to make the advertisement more attractive and readable. As seen, the slogan is an important element in the advertisement. Surprisingly, not all the examples in our corpus contain a slogan. Even more stunning is, as Trehan (2006: 121) states, "generally $20 \%$ of the readers do not go further than reading headlines". This is not what happens with the official associations, which release one slogan every year. They try to be catchy and remembered for good. As Skorupa says (2015), slogans are the most effective means of drawing the attention of the general public or consumer based on one or more aspects of a product, while visual or audio material only help to consolidate the slogans in the customer's minds (109).

Related to the content, this sample is peculiar as, contrary to traditional advertisements that want to attract the attention and be impressive, what they really show is a regular and daily life. That is, normality is the paradoxical message in the videos.

\section{Research tools}

This study contains two types of information: general and specific. The items and results are shown in tables one and two. The table number one reflects the data in the videos recorded in Spain and the table number two reflects the videos released on the above-mentioned date in the United States of America. Firstly, we have considered the duration of the video; that is, the length of time which the video takes. Secondly, the number of views and likes at the moment of the study have been regarded. We have also highlighted the comments received in every video although the content of those comments has not been analysed. The first group reflects the acceptance of the community to the videos, for their attractiveness or content.

There is a second informative block in the tables that comprise the appeal of the videos. This is divided up into two groups: emotive, where no information is provided in the sample but nice pictures with music; and informative, where information about their daily lives and feelings are shown. There is another classification, whether they are live-performance or home-made videos; or viral, this second group are the videos mostly done by the associations. We have also reflected the age of the participants: they are kids, teenagers or adults. Most adults do not have the genetic condition.

Many of the videos have also a title. This can be the slogan used in the campaign of the year or any other with which they want to attract the attention. In some occasions they also provide information about the authorship. We have also added a column called "comments". In this case, some relevant information about the video is provided.

With these elements, all the structural and content features of the videos are covered. The most remarkable and common characteristics according to the acceptance expressed by the audience and the possible differences between both countries will be highlighted.

\section{Results}

Generally speaking, the duration of the videos is around 4' as an average with the exception of the programs recorded and uploaded to the net but the time stated is estimated to be enough to release the message. Added to 
this, as we shall see later, the number of views and likes is closely related to the origin of the video: the more professionally done, the more views and likes. Thirdly, two thirds of the videos are informative, not emotive although in Spain the number of informative videos is higher. Kids and teenagers are shown in the same proportion in Spain, but The States prefer to show kids rather than teenagers.

If we go further, the videos taken as a whole can be divided up into two big groups. On the one hand, we have the official videos in which Down España and The States release a slogan. Then, the different associations record their contribution. In the year studied the slogan was "Authentic". Authentic because they are genuine, true to themselves, not false. These videos are mostly professional, although not all. Music and pictures are well chosen. The message is emotional rather than informative. They are viral.

The second group are the live-performed records. Anonymous people want to share their experience with people with Down Syndrome or representatives that show their daily living. This second group is much more domestic. They explain their household affairs and home life. The main purpose is being informative, to show the reality in their daily life with first hand interviews. However, the number of views, likes and comments is remarkably shorter than in the previous group.

If we compare both tables, although the content is varied, there are some patterns to be highlighted: Firstly, in Spain the approach of the parents to this circumstance is shown. There is a call to future parents that will experience something unexpected. In this group no kids appear. Secondly, friends and relatives with the kids themselves are mentioned. In this case, some elements of humour appear and, thirdly, where the only characters that appear are the persons with Down Syndrome, whether talking in a kind-like interview or just performing their daily life. In all the cases the need to see these persons with different eyes is the message. According to the way of doing this, in most cases videos are informative and just in three examples, emotive. This last group, with three examples overall, does not provide information but just makes us see young kids as caring. It is remarkable the example of 50 mothers that sing in English. Actually, this is a foreign advertisement which was released in a Spanish media. The views of this video are over two hundred thousand at the moment of the study and what they simply do is to sing a song in a car with their 4-year-old son with Down Syndrome by using the sign language.

It is remarkable the scarce number of fathers or males that appear. As an exception, it is worth highlighting the home-made video done and published by David Roca entitled "necesitamos a David" ("We need David") in which he explains what down symdrome means in the daily routine and why his brother is so special. Just a picture of his brother appears in the video. The video is very simple but straight and has got close to two thousand five hundred views. Furthermore, the age of the characters is quite balanced: teenagers and kids appear with the same proportion but adults hardly appear. There is an exception in the video "eso no se pregunta" ("this is not asked"). Surprisingly, the adult is the person who says he is not happy.

Videos in table 2 are mostly characterised by young children or teenagers. Children are seen as nice kids to whom caring and compassion is the feeling they provoke while, as teenagers, they are shown like independent and self-sufficient persons. The physical image is reflected to be the only barrier which we establish in our subconscious as they do not demand any other right than being treated as any other. May videos be released like blogs of a specific family that shows from time to time the daily life of a member with Down Symdrome, not as an isolated example. 
On the other hand, some of the videos done in North America remark the idea of what teenagers can provide to society. Thus, most of them are informative and, in this case, self-recorded. Viral videos are released in TV programs or done by associations. As said before, this last case is the song sung by 50 mothers with their 4 yearold kids recorded in their cars by their husbands. The TV program also invites the mothers with their kids while the husbands are out of cameras. In this case, it is also very scarce the visual contribution of the fathers.

The songs repeated in the sample are three: "A thousand years" by Christina Perri; "This is me" by The Greatest Showman; and the use of the title of the song "I wouldn't change a thing" by Joan Jonas \& Demi Lovato in a campaign, but not the song itself.

\section{Discussion and Conclusion}

Target audience's attitude is different when an advertisement is displayed with commercial aims rather than with social awareness and this is not overlooked by advertisers. The way of approaching to a wider number of viewers is to switch tactics. Therefore, predicting the different ways with which people can be touched by an idea will be an invaluable tool for spreading it. Rather than searching for differences in the way of appreciating a collective, it is important to find ways to overcome differences and see how to identify beliefs and attitudes that unite different audiences.

These ways are varied. On the one hand, viral videos prefer to develop the attractiveness and emotional side in the display rather than usefulness. Indeed, the videos done by the international partnerships are to be seen around the world, therefore the use of music and attractive images are the two fundamental pillars in them and not the verbal messages. This is not difficult to get with elements, such as kids, caring mothers and sweet music.

On the other hand, home-made videos are focused on usefulness; that is, providing real information about this collective. They are not viral but many of them have a high acceptance. They show another way of becoming visible and is by showing their daily routine. The most difficult part of this is that they actually show what the rest of the citizens do take it for granted. The striking of the videos is that these rights cannot be denied to them.

Secondly, the lack of adults with Down Syndrome in the videos and that the only one that appears expresses his unhappiness leads us to believe that there have been achievements for the last decades. Integration and acceptance are becoming a reality. Thirdly, PSAs have the aim of spreading an idea that implies a swift change in the way that society thinks. In our study, we have seen that this change is more difficult to obtain when the aim is to normalize and see like equals a collective of people. The way of reflecting it has to avoid the exaggeration but be catchy. The way of doing it in our sample is to promote a positive social image. To do this, people are shown in a relaxed atmosphere, glad, chatty, with sense of humour and answering some questions in an interview. Spontaneity is perceptible.

Fourthly, most Spanish videos use slogans in their videos in a higher proportion than in America. Titles like "Yo Contenta" ("Me happy") are seen with others like "Yo Down" ("Me Down"), "El mundo al revés" ("The world upside down") or "Cambia tu Mirada sobre el Síndrome de Down" ("Change your look/ view about Down Syndrome"). As seen, some of them are witty and play with words. In the case of American titles, the number is scarce and, apart from the viral "Wouldn't change a thing" that makes reference to a song too, we find "Things Down Syndrome bring to society" or "Jus a glimpse to our average". They are humourless and, as said, there are fewer examples. 
It is also remarkable the lack of father's physical appearance in front of the cameras with some exceptions. In these exceptional cases, they are interviewed about their experience with children with Down Syndrome or sing a song with their childen playing a guitar. In the viral " 50 mums, 50 kids, 1 extra chromosome" the videos are recorded by the fathers. Mothers are shown courageous in supporting their children's rights and show it in many different ways.

To sum up, the disadvantage of spreading an idea with this collective compared with others is that the reasons for the lack of integration are not so well defined as in other issues like drugs, alcohol or reckless driving. Indeed, in these last examples the youth build what is called "the youth culture fortress" where doctors, police, parents, government and all that represents stablishment is out of that fortress; and drugs, style press, dance radio stations, nightclubs, DJs and all that is considered their life is inside that fortress.

In the collective studied in this paper, it is the group we deal with who want to open that fortress and integrate themselves with the rest of society. When the door is opened, it is the society who does not see them as equal or worth of integration. The fact that people with Down Syndrome own some physical characteristics does not look enough reason; the fact that they can have difficulties for the development of some tasks can be closer to reality. That is the reason why the main aim of these advertisements for every institution is to show that they can live and behave like independent persons in all key aspects.

We have stated the main differences between traditional adverts and public service ones. Being the aim different, the tools and means used are not expected to be similar. Besides, with the classification offered we have seen the close relationship that there exists between the origin of the video and its virality. Self-recorded videos have less views and likes than the videos done by the associations, no matter the content of it, with very few exceptions. The two big groups that appear in reference to the appeal make us conclude that informative videos are much more common than emotive, being the videos characterized by teenagers, informative. Their demand to be considered citizens with their own rights is expressed straight.

On the other hand, videos released by official associations try to catch the attention by being original and attractive, not informative. This year's video called " 50 mums, 50 kids, 1 extra chromosome" has received more than four million views in the English release and more than two hundred thousand with Spanish subtitles. The song chosen is "A thousand years" and the slogan "Wouldn't change a thing" making reference to another popular song. Mothers sing the song using sign language winking to another disability. Nevertheless, the message itself is just to show the happiness that families feel with their kids with trisomy.

All in all, we have seen that most viral videos are not the ones with a straighter message. Both ways of demanding being treated as normal citizens combine in a harmonic way. The lack of information that could have one is supplied with the excess of sentimentality that provides the other. Combining both elements in the same record could create confusion in the viewer and the purpose would be blurred.

Remarkable is also the fact that videos in Spain want to show a relaxed and funny atmosphere among the protagonists and in the American videos added to this, there exists the subtle message of usefulness. That is, this people will also be useful for society, they will be productive. This is hardly seen in the Spanish videos.

A further analysis could be a study of the slogans in the Public Service Advertisements from a linguistic viewpoint in order to see whether they contain outstanding differences with the commercial advertisements. 
Although the main difference between both is in the final aim of the advert, the means used should not be so divergent.

\section{Primary sources}

\section{Videos in Spain}

Día Mundial Del Síndrome De Down Día Mundial del Síndrome de Down 2018. https://www.youtube.com/watch?v=r4IlEgG5krE Accessed 22 March 2018.

Y Tú, ¿Qué Le Dirías? - Día Internacional Del Síndrome De Down - Asalsido Down Almería https://www.youtube.com/watch?v=kGP9urvvjzk\&t=144s Accessed 22 March 2018

Auténticos Down España Día Mundial del Síndrome de Down 2018 https://www.youtube.com/watch?v= kb8mJ0r8Guk Accessed 22 March 2018

Punto y coma Día Internacional del Síndrome de Down https:/www.youtube.com/watch?v=11h4VE7Dd64\&t=4s Accessed 22 March 2018

Día sindrome de Down https://www.youtube.com/watch?v=FDE0g4da9u8 Accessed 22 March 2018

Día mundial del Síndrome de Down 2018 https://www.youtube.com/watch?v=5izkXqfViiY\&t=25s Accessed 22 March 2018

21 de marzo Día Mundial del Síndrome de Down https://www.youtube.com/watch?v=V39Nzn4BzlM Accessed 22 March 2018

Día Mundial del Síndrome de Down: Chloe tiene algo que pedirnos https://www.youtube.com/watch?v=8Nq7iixN0WA Accessed 22 March 2018

Amor sin condición https://www.youtube.com/watch?v=es34Nr2JovU Accessed 22 March 2018

Día Internacional del Síndrome de Down https://www.youtube.com/watch?v=BV24AAiRTnU Accessed 22 March 2018

Wouldn't change a thing “La Vanguardia” https://www.youtube.com/watch?v=xYvJReaodEE Accessed 22 March 2018

Síndrome Contenta https:/www.youtube.com/channel/UCOuUjxGFo-EfNRvcPM-ORiw Accessed 22 March 2018

Patri Fashion Time https://www.youtube.com/watch?v=iImXKGfvFPE Accessed 22 March 2018

Somos Auténticos https://www.youtube.com/watch?v=kb8mJ0r8Guk Accessed 22 March 2018

Yo Down https://www.youtube.com/channel/UC1koQSpVE1CxPwFEgmFr5DQ Accessed 22 March 2018

Fundación Murcia https://www.youtube.com/watch?v=OqNqrSDS1hg Accessed 22 March 2018

El mundo al revés https://www.youtube.com/watch?v=0BQgxUZKUp0 Accessed 22 March 2018

Necesitamos a David https://www.youtube.com/watch?v=TKy4ZlanPrg Accessed 22 March 2018

\section{Videos in USA}

21 Things We Love About Rosie! World Down Syndrome Day 2018 https://www.youtube.com/watch?v=YLTxoNoBIzQ Accessed 22 March 2018

World Down Syndrome Day 2018 https://www.youtube.com/watch?v=IwJfF4RQ-is Accessed 22 March 2018

The Mums Behind the Viral 'A Thousand Years' Down's Syndrome Video This Morning https://www.youtube.com/watch?v=JjScme_Jxs Accessed 22 March 2018

Celebrating Sophie and World Down Syndrome Day 2018 https://www.youtube.com/watch?v=bihneIEcEDw Accessed 22 March 2018 
Conor McGregor Celebrates World Down Syndrome Day https://www.youtube.com/watch?v=UvwoPDXvvWw Accessed 22 March 2018

50 Mums 50 Kids 1 Extra Chromosome https://www.youtube.com/watch?v=Biex1XR_mpo Accessed 22 March 2018

Lea Goes To School March 21 - World Down Syndrome Day \#IncludeUsFromTheStart https://www.youtube.com/watch?v=1_QGlbwwCy4 Accessed 22 March 2018

321 World Down Syndrome Day https://www.youtube.com/watch?v=yhuvysvKGGM Accessed 22 March 2018

World Down Syndrome Day. Tom's Story https://www.youtube.com/watch?v=B86gnNXwoh4 Accessed 22 March 2018

World Down Syndrome Day Interview https:/www.youtube.com/watch?v=mr4w8m9YRh4\&t=23s Accessed 22 March 2018

Wouldn't change a thing https://www.youtube.com/channel/UC2A1z2y3EENrQ6NjLUsGHAA Accessed 22 March 2018

Down syndrome Beth Herrington https://www.youtube.com/watch?v=IwJfF4RQ-is Accessed 22 March 2018

Corinee Thompson https://www.youtube.com/watch?v=6VAjnVeWagE Accessed 22 March 2018

The Christian Institute https://www.youtube.com/watch?v=GZZkjFS4Ec0 Accessed 22 March 2018

Lily’s Journey https://www.youtube.com/watch?v=9E8z0_qfjnM Accessed 22 March 2018

Down syndrome of Louisville https://www.youtube.com/watch?v=k23Bi7rxhQs Accessed 22 March 2018

Down Syndrome Zimmerman https://www.youtube.com/watch?v=r-jE2GYEcUE Accessed 22 March 2018

\section{References}

Aijmer, K. (ed.) (2004). Discourse Pattern in Spoken and Written Corpora, Amsterdam: John Benjamins.

Berger, J.A. and Milkman, K.L. (2009). What makes online content viral?,working paper series SSRN, available at: http://ssrn.com/abstract1/41528077; http://dx.doi.org/10.2139/ssrn.1528077 (accessed July 10, 2012).

Berrocal, S., Domínguez, E. C., \& García, M. R. (2012). El «infoentretenimiento» en Internet. Un análisis del tratamiento político de José Luis Rodríguez Zapatero, Mariano Rajoy, Gaspar Llamazares y Rosa Diez en YouTube, Doxa Comunicación: revista interdisciplinar de estudios de comunicación y ciencias sociales, (15), 13-34.

Biber, D. (1988). Variation across Speech and Writing, Cambridge: Cambridge University Press.

Boitor, B., et al. (2011). Impact of New Online Ways of Advertising. Bulletin of the Transilvania University of Brasov.Economic Sciences.Series V 4.2: 11-8. Print.

Brown, G. \& Yule, G. (1986). Discourse Analysis, Cambridge: Cambridge University Press.

Collin, W. (2008) in Lannon, J (ed.) How Public Service Advertising Works World Advertising Research Center.

Cook, G. (1992). The Discourse of Advertising, London: Routledge.

Duboviciene, T \& Skorupa, P. (2015). Linguistic characteristics of commercial and social advertising slogans, Coactivity: Philology, Educology 23.2: 108-118.

Duranti, A. (1983). Samoan Speechmaking across Social Events: one genre in and out of a fono. Language in Society 12.1: 1-22.

Fuhrel-Forbis, A., Gayle Nardoff, P. \& Snyder, L. (2011). Analysis of Public Service Annoncements on National Television, 20012006, Social Marketing Quarterly 15.1 49-69.

Gladwell, M. (2002). The Tipping Point: How Little Things Can Make a Big Difference, Boston: Back Bay Books.

Kaplan, A.M. and Haenlein, M. (2010). Users of the world, unite! The challenges and opportunities of social media, Business Horizons, 53(1): 59-68.

Khan, G. F., and S. Vong. (2014). Virality Over YouTube: An Empirical Analysis. Internet Research 24(5): 629-47. Print. 
Labrador, B., Ramón, N., Alaiz-Moreton, H. \& Sanjurjo-Gonzalez, H.. (2014). Rhetorical Struture andd Persuasive Language in the Subgenre of Online Advertisements, English for Specific Purposes 34: 38-47.

McCarthy, M. (1998). Spoken Language and Applied Lingusitics. Cambridge: Cambridge University Press.

Paek, H., Hove, T. \& Jeong, H.J. (2011) Peer or Expert? The persuasive Impact of YouTube Public Service Announcement Producers, International Journal of Advertising, 30(1): 161- 188.

Porter, L. and Golan, G.J. "From subservient chickens to brawny men: a comparison of viral advertising to television advertising", Journal of Interactive Advertising, 6.2 (2006): 30-38.

Pousttchi, K. and Wiedemann, D.G. (2007). Success factors in mobile viral marketing: a multi-case study approach, paper presented at the Management of Mobile Business, ICMB 2007, International Conference, July 9-11.

Rowse, E. J. \& Fish, L. J. (2005). Fundamentals of Advertising. USA: Kassinger Publishing.

Sádaba, I., \& Rendueles, C. (2016). Metodologías de análisis del espacio audiovisual online: Entre la innovación y la ansiedad de la novedad/Methodologies for the analysis of online audiovisual space: Between innovation and anxiety of novelty. Empiria, (35), 105.

Schlosser, A.E., Shavitt, S. \& Kanfer, A. (1999). Survey of internet users'attitudes toward internet advertising, Journal of Interactive Marketing 3(13): 34-54.

Storey, R. (2008) in Lannon, J (ed.) How Public Service Advertising Works, World Advertising Research Center.

Trehan, Mukesh and Ranju Trehan (2006). Advertising and Sales Management. 2nd ed. Delhi: Prince Print Process

Tuten, T. L. (2008). Advertising 2.0 Social Media Marketing in a Web 2.0 World, London: Praeger

Williams, D., Sullivan, S.J.; Schneiders, A.G.; Ahmed, O.H.; Lee, H.; Balasundaram, A.P. \& McCrory, P.R. (2014) Big Hits on the Small Screen: an Evaluation of Concussion-Related Videos on Youtube. British Journal of Sports Medicine, 48(2): 107-111.

Yang, K. C. et al. (2017). Consumer attitudes towards Online Video Advertisement: Youtube as a Platform. Kybernetes 46(5): 840-53. 